\title{
The Impact of Dynamic Capabilities on Sustainable Competitive Advantage in the Pharmaceutical Sector in Egypt
}

\author{
Albert Naiem Naguib ${ }^{1}$, Eahab Elsaid ${ }^{2} \&$ Abdel Moneim Elsaid ${ }^{3}$ \\ ${ }^{1}$ Marcyrl Pharmaceutical Industries, El-Obour City, West Extension, Block 20005 , Cairo, Egypt \\ ${ }^{2}$ Finance Department, Odette School of Business, University of Windsor, 401 Sunset Ave., Windsor, Ontario, N9B \\ 3P4, Canada \\ ${ }^{3}$ Faculty of Commerce, Ain Shams University, Khalifa Mamon St., Abassya, Cairo, Egypt \\ Correspondence: Eahab Elsaid, Finance Department, Odette School of Business, University of Windsor, 401 Sunset \\ Ave., Windsor, Ontario, N9B 3P4, Canada
}

Received: March 28, 2017

Accepted: April 13, 2017

Online Published: April 18, 2017

doi:10.5430/bmr.v6n2p1

URL: https://doi.org/10.5430/bmr.v6n2p1

\begin{abstract}
This study examines the relationship between dynamic capabilities (experience, routine, skills, firm characteristics, knowledge and technology) and competitive advantage sustainability in the Egyptian pharmaceutical sector. The data was collected using primary and secondary data sources. Primary data was collected from questionnaires distributed to 160 top managers in 20 pharmaceutical firms. The secondary data about pharmaceutical firms like rankings, revenues and market share was collected from external sources such as Intercontinental Marketing Service (IMS). The questionnaires examine six independent variables based on a five-scale Likert scale. The methodology used in the study is non-probability sampling (judgmental sampling), Cronbach's alpha reliability coefficient and Chi-square tests. The results support the notion that there is a significant relationship between four of the six dynamic capabilities (experience, skills, firm characteristics and knowledge) and the competitive advantage sustainability for pharmaceutical firms in Egypt. Designing the questionnaire and formulating the questions to target the required field was challenging, given that the topic is dynamic and the business scene in Egypt has witnessed drastic political changes since January 2011. The study should assist pharmaceutical companies in Egypt in directing their investments properly and in determining the weaknesses in their dynamic capabilities that need to be addressed.
\end{abstract}

Keywords: Egypt, pharmaceutical sector, Dynamic capabilities, Competitive advantage, Resource Based theory

\section{Introduction}

Many theories have been proposed to explain what causes firms to have a sustainable competitive advantage, what leads firms to perform well in the market and occupy a superior position among rivals. There are major themes which emerge repeatedly throughout the literature. Two of these themes are: (1) resources and how they help to build a sustainable competitive advantage and (2) dynamic capabilities, such as, experience, routine, skills, firm characteristics, knowledge and technology and how these capabilities affect firm performance. Although the literature presents these themes in a variety of contexts, this paper will primarily focus on the role of the dynamic capabilities in building a sustainable competitive advantage.

Andrews (1971) introduced the concept of core competence and described it as what the firm can do specifically well. Frery (2006) described core competencies as the basic building blocks for a firm's corporate strategy. Prahalad and Hamel (1990) explained that core competencies are like the roots of a tree that provide it with nutrition, life and stability. Mahoney and Pandian (1992) indicated that a firm can achieve profits, not because of its unique resources, but because of its distinctive competences and the usage of its resources. Littler (2005) highlighted two essential qualities of core competence. First, a core competence must be a capability of a firm rather than the limited ownership of a resource. Second, a core competence should help the firm achieve its goals, for these goals are central to a firm's value-generating activities.

Rouse and Dallenbach (1999) indicated that, for the past two decades, the concept of competitive advantage has been central to the practice and study of strategic management. Porter (1985) argued that a firm's ability to outperform its rivals lay in its ability to translate its competitive strategy into a competitive advantage. Barney (1991) argued that 
the competitive advantage can be achieved if the firm's strategy is value added and difficult to imitate by rivals in the present or near future. Eisenhardt and Martin (2000) stated that sustainable competitive advantage occurs when the firm's dynamic capabilities are not only valuable and rare, but also inimitable. Porter (1991) claimed that a firm's possession of a resource alone will never guarantee competitive advantage. In the same vein, Ambrosini et al., (2009) stated that in order for a resource to generate value, it must be utilized by the firm in a distinctive organizational process or routine.

\section{Literature Review}

\subsection{Resource Based Theory}

The Resource based theory stipulates that companies have collections of resources that result in competitive advantages (Barney, 1991). The more unique and inimitable those collections of resources, the better the firms' competitive advantage (Shrader et al., 1997). Penrose (1959) classified resources as land, equipment, labor, capabilities, knowledge, and organizational capital either tangible or intangible. Therefore firms can generate rents when resources are firm specific, and the existence and maintenance of rents depends on the difficulty of competitors to attain, imitate, or develop those resources. Barney (1991) classified firm resources into three categories: physical resources, organizational resources and human resources.

Andrews (1971) and Porter (1985) came up with two models in the field of strategic human resource management and competitive advantage. The first one is the resource based model "internal analysis." The resource-based model examined the link between the internal characteristics of a firm and firm performance and it stated that the firm's resources must be valuable, rare, inimitable and non-substitutable in order for the firm to possess a distinct competitive advantage. The second model is the environmental model of competitive advantage "external analysis".

\subsection{Dynamic Capabilities}

Liqin et al., (2010) emphasized the importance of both resources and capabilities and they formulated a "capability-based model" as an evolved concept of the resource-based theory. The capability-based model proposes that the success of an organization's strategy fully relies on the ability of transforming the resources to a competitive advantage. Therefore it actually moves the literature a step closer to recognizing how organizations evolve and sustain their sources of competitive advantage. Makadok (2001) differentiated between capabilities and resources and defined capabilities as organization specific resources, to help leverage profit and performance.

Teece (1998) defined dynamic capabilities as "the organization's tendency to integrate, build and reallocate its internal and external resources to cope with changing environments". More recently, Eisenhardt and Martin (2000) stated that dynamic capabilities contain specific, strategic and organizational processes like product development and strategic decision making that create value for firms within dynamic markets by manipulating resources into new value-creating strategies. Bowman and Ambrosini (2003) coined the "dynamic capability approach" and focused attention on the firm's ability to renew its resources in line with changes in its environment. Sitkin (1992) states that mistakes also play a role in the evolution of dynamic capabilities; small losses, more than either successes or major failures, contribute to effective learning.

Winter (2003) identified the dynamic capabilities hierarchy as including: (1) experience, (2) routine, (3) skills, (4) firm characteristics, (5) knowledge and (6) technology. These six capabilities are part of this study's research model.

\subsubsection{Experience}

King and Tucci (2002) argue that experience leads to habitual routines that reinforce existing practices and assist adaptation. They classified experience into two styles: (i) static experience which is gained from further elaboration of existing structures, positions, and strategies and (ii) transformational experience which is gained from changing these attributes. The evolution of dynamic capabilities is also affected by the pace of experience. Argote (1999) states that experience which was built rapidly can confuse managers and lead to hindering the transformation of this experience to useful learning. On the other hand, when the experience accumulation becomes irregular it can lead to forgetting what was learned and consequently cause little knowledge accumulation.

\subsubsection{Routine}

Ray et al., (2004) defined the routine or business processes as the activities that organizations engage in order to achieve their targets. Zollo and Winter (2002) found that dynamic capabilities are gained and perfected through activities were the organizations produce and modify their operating routines for the sake of development. Barney (1991) stated that higher-order routines, which are more difficult to transfer, may help firms to sustain a competitive advantage. While Kogut and Zander (1992) argued that higher-order routines are difficult for rivals to imitate 
because they are socially complex. Aime et al., (2010) show that hiring key employees from a competitor that possesses an advantageous set of routines will enhance the competitive position of the hiring organization and in turn improve the organization's performance.

\subsubsection{Skills}

Robles (2012) defined skills as the individual's ability to do something well. Porter (1987) argued that transferring skills in organizations leads to competitive advantage. Audea et al., (2005) found that there is a strong relationship between firm performance and employee training. Browning et al., (2009) emphasized the importance of training to build skills and knowledge inside the organization.

\subsubsection{Firm Characteristics}

Firm characteristics play a crucial role in building an organization's competitive advantage. Winter (2003) and Bharadwaj et al., (1993) indicated that firm characteristics include, firm size relative to competitors (e.g., market share and customer base), business portfolio composition, and the firm's order of entry into the market. Audea et al., (2005) state that larger firms tend to be more associated with higher levels of overall firm performance. Bharadwaj $e t$ al., (1993) claimed that large organizations possess more of a competitive advantage than the small organizations. On the contrary, Chen (1996) argued that the small size firms are better able to cope with the changing environmental dynamics than large firms since they are more fixable and agile. Bharadwaj et al., (1993) emphasized the importance of a firm's order of entry into a market and concluded that the pioneers or first-movers have higher market shares than late entrants. Bharadwaj et al., (1993) also indicate that the number of products that the firm produces does affect the firm's financial and market position among rivals.

\subsubsection{Knowledge}

Hansen (1999) indicated that knowledge is a crucial dynamic capability in industries like pharmaceuticals and that the transfer of knowledge helps in the reallocation of resources within organizations which is essential for an effective strategy and superior performance. Williams and Leask (2011) argued that knowledge involves a human element factor that helps in building a competitive advantage in an organization. The human element includes motivating employees so that they are willing and able to learn and share knowledge. This will be ultimately reflected in customer satisfaction which in turn will build trust and loyalty. The human element contains a number of processes, such as capturing, transferring, sharing, applying and creating new knowledge within employees. Azarian et al., (2013) indicated that the knowledge transfer among employees inside the organization or the transfer of knowledge from one group of employees to the next enhances productivity.

\subsubsection{Technology}

Utterback and Abernathy (1975) introduced the concept of "dominant design" which proposed that the emergence of a dominant design is the cornerstone in an industry evolving and changes the way that organizations compete in a particular industry. A dominant design can be a new product or a set of new features on an already existing product. Technology allows organizations to manage their functions to create a competitive advantage that allows the firms to create a dominant design. Foster (1986) highlighted the importance of the technology and how it affects the firm performance and discussed "the technology S-curve" that helps in understanding the shape of the technology lifecycle. Davenport et al., (2003) emphasized that firms should have a technology strategy that considers the emergence of new technologies, that changes to cope with market dynamics and that adjusts based on the nature of competition with the firms' competitors.

\subsection{Overview of the Egyptian Pharmaceutical Sector}

The sales value in the Egyptian pharmaceutical sector from January $1^{\text {st }}, 2015$ to December $31^{\text {st }}, 2015$ according to the Egyptian stock market magazine report issued on March $9^{\text {th }}$, 2016, was 4.1 billion U.S. dollars with a $4 \%$ growth from the previous year. The report discovered that 20 pharmaceutical firms accounted for almost 55\% of the pharmaceutical market share in Egypt. Of those 20 firms, 11 are multinational firms and 9 are Egyptian firms. Moreover the report indicated that of those 20 pharmaceutical firms the first 10 firms on the list control $38 \%$ of the market share while the other 10 firms control $17 \%$ of the market share. The Egyptian pharmaceutical sector's growth in U.S. dollars in 2015 entered into a stage of risk which is around $4 \%$ according to Intercontinental Marketing Service (IMS, 2015). This is due to the increase in the value of the U.S. dollar against the Egyptian pound and the stability of the prices of pharmaceutical products which in turn led to the erosion of corporate profitability. 


\section{Data Collection and Methodology}

\subsection{Research Question}

The research question for this study is as follows: To what extent do dynamic capabilities (experience, routine, skills, firm characteristics, knowledge and technology) inside the organizations affect the building of competitive advantage sustainability in the pharmaceutical sector in Egypt.

\subsection{Hypotheses}

The purpose of this paper is to help determine which of the dynamic capabilities (experience, routine, skills, firm characteristics, knowledge and technology) enable the pharmaceutical firms in Egypt to create and/or maintain their competitive advantage sustainability. To achieve the objectives of the study, the following hypotheses have been formulated:

H1: There is a significant relationship between the "experience" dynamic capability and the competitive advantage sustainability in Egyptian pharmaceutical firms.

H2: There is a significant relationship between the "routine" dynamic capability and the competitive advantage sustainability in Egyptian pharmaceutical firms.

H3: There is a significant relationship between the "skills" dynamic capability and the competitive advantage sustainability in Egyptian pharmaceutical firms.

H4: There is a significant relationship between the "firm characteristics" dynamic capability and the competitive advantage sustainability in Egyptian pharmaceutical firms.

H5: There is a significant relationship between the "knowledge" dynamic capability and the competitive advantage sustainability in Egyptian pharmaceutical firms.

H6: There is a significant relationship between the "technology" dynamic capability and the competitive advantage sustainability in Egyptian pharmaceutical firms.

Data was collected from primary and secondary sources. The secondary data about pharmaceutical firms like rankings, revenues and market share was collected from external sources such as the Intercontinental Marketing Service (IMS is a multinational company responsible for collecting and analyzing data about pharmaceutical firms with regards to their market share, revenues, sales and many other statistics about the disease area market description and competitors).

The primary data source was the questionnaires that the authors distributed to top managers such as: Chief Executive Officers (CEOs), Chief Financial Officers (CFOs), Chief Operating Officers (COOs), heads of departments like HR managers, training managers, marketing managers, operations managers and IT managers. It is important to note that designing the pattern of the questionnaire and formulating the questions to target the required field was challenging, given that the topic is dynamic and the business scene in Egypt has witnessed drastic changes since the political upheaval that started in January 2011. The questionnaires tackle six independent variables and include seventeen questions using a five-scale Likert scale ranging from 1 for "strongly disagree" to 5 for "strongly agree."

\subsection{Sample}

The sample consists of 160 respondents from top management who represent the decision makers inside their organizations. Eighty managers are from the top-ten ranked pharmaceutical firms in Egypt, and the other 80 managers are from non-ranked companies according to the International Finance Corporation (IFC, 2015) and the Intercontinental Marketing Service (IMS, 2014/2015) definition. The selection of the respondents was based on the "judgmental sampling" technique which is a nonprobability sampling technique (Higginbottom, 2004, Greenberg et al., 1977). This sampling technique is also referred to as purposive sampling or authoritative sampling. The "unit of analysis" in this study is the firm even though the decisions are made by individuals in these firms who represent their firms' strategic decision and the "population" in this case is the top management such as: CEOs, CFOs, COOs and heads of departments.

\subsection{Questionnaire}

The questionnaire is divided into six sections to investigate if the dynamic capabilities (experience, routine, skills, firm characteristics, knowledge and technology) that are being examined have a role in building a sustainable competitive advantage. The questions were designed to examine if applying certain functions and processes periodically within the company would guarantee its dynamism with regards to market changes. 
The questionnaire was designed in Arabic since not all of the 160 respondents in our sample are proficient in English. The decentring method by Werner and Campbell (1970), which is commonly used in cross-cultural research (Brislin, 1976) was used to translate the questionnaire from Arabic to English. The questionnaire was originally in Arabic, and one of the authors who is a fluently bilingual native Egyptian translated the questionnaire into English. A different author who is also a fluently bilingual native Egyptian blindly translated the questionnaire back into the original language, Arabic. The original and translated Arabic language questionnaires were compared and examined for differences and it was determined that there were no differences between the two Arabic language questionnaires. Thus, no adjustments were needed. The questionnaire is available in the appendix.

\section{Findings}

The study's descriptive statistics focused on the mean as a measure of central tendency. The Likert scale measured the sample's responses as follow 1. Strongly Disagree; 2. Disagree; 3. Neutral; 4. Agree; 5. Strongly Agree. The independent variables (dynamic capabilities) are ordinal in nature and Likert scale was used to order and rank them and the dependent variable (rankings) is continuous in nature processing with time (Hair et al., 2010).

Table 1.

Panel A: The descriptive statistics for the experience items

\begin{tabular}{lll}
\hline & Question 1 & Question 2 \\
\hline N Valid & 160 & 160 \\
Missing & 0 & 0 \\
Mean & 4.34 & 4.30 \\
Median & 4.00 & 4.00 \\
Standard Deviation & 0.525 & 0.559 \\
Minimum & 3 & 3 \\
Maximum & 5 & 5 \\
\hline
\end{tabular}

Panel B: The descriptive statistics for routine items

\begin{tabular}{llll}
\hline & Question 1 & Question 2 & Question 3 \\
\hline N Valid & 158 & 160 & 160 \\
Missing & 2 & 0 & 0 \\
Mean & 3.16 & 3.21 & 3.01 \\
Median & 4.00 & 3.00 & 3.00 \\
Standard Deviation & 1.145 & 1.193 & 1.113 \\
Minimum & 1 & 1 & 1 \\
Maximum & 5 & 5 & 5 \\
\hline
\end{tabular}

Panel C: The descriptive statistics for skills items

\begin{tabular}{llll}
\hline & Question 1 & Question 2 & Question 3 \\
\hline N Valid & 160 & 160 & 160 \\
$\quad$ Missing & 0 & 0 & 0 \\
Mean & 4.08 & 4.10 & 3.69 \\
Median & 4.00 & 4.00 & 4.00 \\
Standard Deviation & 0.757 & 0.626 & 0.972 \\
Minimum & 2 & 2 & 2 \\
Maximum & 5 & 5 & 5 \\
\hline
\end{tabular}


Panel D: The descriptive statistics for firm characteristics items

\begin{tabular}{ll}
\hline & Question 1 \\
\hline N Valid & 160 \\
Missing & 0 \\
Mean & 4.21 \\
Median & 4.00 \\
Standard Deviation & 0.788 \\
Minimum & 2 \\
Maximum & 5 \\
\hline
\end{tabular}

Panel E: The descriptive statistics for knowledge items

\begin{tabular}{llll}
\hline & Question 1 & Question 2 & Question 3 \\
\hline N Valid & 160 & 160 & 160 \\
Missing & 0 & 0 & 0 \\
Mean & 4.34 & 4.41 & 4.44 \\
Median & 4.00 & 4.00 & 4.00 \\
Standard Deviation & 0.548 & 0.494 & 0.498 \\
Minimum & 3 & 4 & 4 \\
Maximum & 5 & 5 & 5 \\
\hline
\end{tabular}

Panel F: The descriptive statistics for technology items

\begin{tabular}{llllll}
\hline & Question 1 & Question 2 & Question 3 & Question 4 & Question 5 \\
\hline N Valid & 160 & 160 & 160 & 160 & 160 \\
Missing & 0 & 0 & 0 & 0 & 0 \\
Mean & 2.92 & 2.88 & 2.79 & 2.76 & 2.79 \\
Median & 3.00 & 3.00 & 2.00 & 2.00 & 2.50 \\
Standard Deviation & 1.298 & 1.285 & 1.455 & 1.376 & 1.384 \\
Minimum & 1 & 1 & 1 & 1 & 1 \\
Maximum & 5 & 5 & 5 & 5 & 5 \\
\hline
\end{tabular}

Panel A of Table 1 lists the descriptive statistics for the questions relating to the extent that experience has a role in building a competitive advantage. The first question is regarding the managers' experience and to what extent it helps them to predict the market change. The second question examines if this experience enables the managers to deal with the market changes easily. The means were 4.34 and 4.30 respectively which support hypothesis 1 and confirm the role of experience in building a sustainable competitive advantage.

Panel B of Table 1 lists the descriptive statistics for the questions relating to the extent that routine has a role in building a competitive advantage. The first question examines if applying quality procedures is taking a big part of company's workforce. The second question examines if the Human Resources department is applying exhaustive procedures in recruiting employees. The third question examines if the company conducts regular employee and customer satisfaction surveys. The means were 3.16, 3.2 and 3.01 respectively which do not support hypothesis 2 and do not confirm the role of routine in building a sustainable competitive advantage.

Panel $\mathrm{C}$ of Table 1 lists the descriptive statistics for the questions relating to the extent that skills have a role in building a competitive advantage. The first question examines if the implementation of a rigid training plan helps the firm in raising its employees' technical skills and/or improving their interpersonal skills which in turn helps the firm 
achieve its targets. The second question examines if continuous training increases the employees' knowledge and awareness about their work and the market in general. The third question examines if the managers delegating some of their authority to their subordinates will improve the subordinates' interpersonal skills like problem solving and decision making. The means were 4.08, 4.1 and 3.69 respectively which support hypothesis 3 and confirm the role of skills in building a sustainable competitive advantage.

Panel D of Table 1 lists the descriptive statistics for the questions relating to the extent that firm characteristics have a role in building a competitive advantage. The first question examines if the firm size and product portfolio have a great impact on the firm's performance in the market. The mean was 4.21 which supports hypothesis 4 and confirms the role of firm characteristics in building a sustainable competitive advantage.

Panel E of Table 1 lists the descriptive statistics for the questions relating to the extent that knowledge has a role in building a competitive advantage. The first question examines if the firm gathers new information continuously. The second question examines if gathering enough information from several different sources, internally and externally, leads to better decision making by the firm. The third question examines if applying horizontal knowledge management improves the firm's decision making process. The means were 4.34, 4.41 and 4.44 respectively which support hypothesis 5 and confirm the role of knowledge in building a sustainable competitive advantage.

Panel $\mathrm{F}$ of Table 1 lists the descriptive statistics for the questions relating to the extent that technology has a role in building a competitive advantage. The first question examines if the firm is using the most up-to-date technology in the market. The second question examines if the updated technology helps the company develop its market position. The third, fourth and fifth questions examines if $R \& D$ is the backbone for the company, if the company is a technology seeker and if the company has a software based knowledge management system respectively. The means were $2.92,2.88,2.79,2.76$ and 2.79 respectively which do not support hypothesis 6 and do not confirm the role of technology in building a sustainable competitive advantage.

Table 2. The descriptive statistics for the complete sample (ranked and non-ranked companies)

\begin{tabular}{lllllll}
\hline & & & & Firm \\
& Experience & Routine & Skills & Characteristics & Knowledge & Technology \\
\hline N Valid & 160 & 158 & 160 & 160 & 160 & 160 \\
Missing & 0 & 2 & 0 & 0 & 0 & 0 \\
Mean & 4.3188 & 3.1308 & 3.9542 & 4.21 & 4.3958 & 2.8275 \\
Median & 4.000 & 3.3333 & 4.000 & 4.000 & 4.3333 & 2.3000 \\
Standard Deviation & 0.49681 & 0.90827 & 0.64481 & 0.788 & 0.38885 & 1.27432 \\
Minimum & 3.00 & 1.33 & 2.00 & 2.00 & 3.67 & 1.00 \\
Maximum & 5.00 & 5.00 & 5.00 & 5.00 & 5.00 & 5.00 \\
\hline
\end{tabular}

Table 2 reports the descriptive statistics for the six dynamic capabilities for the complete sample (160 respondents), 80 respondents from top ranked companies and 80 respondents from non-ranked companies. The experience dynamic capability has a mean of 4.31 which supports hypothesis 1 and confirms the importance of experience in building the competitive advantage. The routine dynamic capability has a mean of 3.13 which rejects hypothesis 2 and does not confirm the importance of routine in building the competitive advantage. The skills dynamic capability has a mean of 3.95 which supports hypothesis 3 and confirms the importance of skills in building the competitive advantage. The firm characteristics dynamic capability has a mean of 4.21 which supports hypothesis 4 and confirms the importance of firm characteristics in building the competitive advantage. The knowledge dynamic capability has a mean of 4.39 which supports hypothesis 5 and confirms the importance of knowledge in building the competitive advantage. The technology dynamic capability has a mean of 2.82 which rejects hypothesis 6 and does not confirm the importance of technology in building the competitive advantage. As a result, examining the complete sample which includes ranked and non-ranked companies shows that both routine and technology are not viewed by top managers as important in building a firm's competitive advantage. 
Table 3. The descriptive statistics for the subsample of non-ranked companies

\begin{tabular}{llllll}
\hline & & & & & \\
& Experience & Routine & Skills & Knowledge & Technology \\
\hline N Valid & 80 & 78 & 80 & 80 & 80 \\
Missing & 0 & 2 & 0 & 0 & 0 \\
Mean & 4.3188 & 2.3974 & 3.9542 & 4.3958 & 1.6650 \\
Median & 4.0000 & 2.3333 & 4.0000 & 4.3333 & 1.8000 \\
Standard Deviation & 0.49838 & 0.58371 & 0.64684 & 0.39008 & 0.46528 \\
Minimum & 3.00 & 1.33 & 2.00 & 3.67 & 1.00 \\
Maximum & 5.00 & 3.67 & 5.00 & 5.00 & 3.00 \\
\hline
\end{tabular}

Table 3 reports the descriptive statistics for the dynamic capabilities for the subsample of non-ranked companies ( 80 respondents). The routine and technology dynamic capabilities have means of 2.39 and 1.66 respectively which reject hypothesis 2 and 6 respectively and does not confirm the importance of both routine and technology in building the competitive advantage in the subsample of non-ranked companies. The results from the subsample of non-ranked companies are similar to the results from the complete sample that included both ranked and non-ranked companies.

Table 4. The descriptive statistics for the subsample of ranked companies

\begin{tabular}{llllll}
\hline & & & & & \\
& Experience & Routine & Skills & Knowledge & Technology \\
\hline N Valid & 80 & 80 & 80 & 80 & 80 \\
Missing & 0 & 0 & 0 & 0 & 0 \\
Mean & 4.3188 & 3.8458 & 3.9542 & 4.3958 & 3.9900 \\
Median & 4.0000 & 4.0000 & 4.0000 & 4.3333 & 4.000 \\
Standard Deviation & 0.49838 & 0.50856 & 0.64684 & 0.39008 & 0.56110 \\
Minimum & 3.00 & 2.00 & 2.00 & 3.67 & 2.00 \\
Maximum & 5.00 & 5.00 & 5.00 & 5.00 & 5.00 \\
\hline
\end{tabular}

Table 4 reports the descriptive statistics for the dynamic capabilities for the subsample of ranked companies ( 80 respondents). The routine and technology dynamic capabilities have means of 3.84 and 3.99 respectively which support hypothesis 2 and 6 respectively and confirm the importance of routine and technology in building the competitive advantage in the subsample of ranked companies. These results are an indication that ranked companies are technology seekers, update their technology including equipment and software and rely on R\&D which is considered the backbone for building a competitive advantage. This is in contrast to the non-ranked companies which do not pay attention and/or interest to R\&D which may be due to the high cost of R\&D. The results also indicate that ranked companies use rigid routines in all their internal processes in contrast to non-ranked companies which display a lack of routine in their internal systems and/or standard operating procedures.

\section{Robustness Tests}

The authors use Cronbach's alpha, which is a reliability coefficient ranging between 0 and 1 , as a robustness check. George and Mallery (2003) indicate that the closer the Cronbach's alpha coefficient is to 1.0 the greater the internal consistency of the items in the scale. However, they consider a Cronbach's alpha of at least 0.7 to be acceptable. On the other hand, Field (2005) argues that when dealing with subjective and/or psychological constructs values below 0.7 are realistic and acceptable because of the diversity of the constructs being measured. 
Table 5 .

Panel A: Cronbach's alpha for the experience construct

\begin{tabular}{lll}
\hline & Cronbach's & \\
& $\begin{array}{l}\text { Alpha Based on } \\
\text { Standardized }\end{array}$ & $\begin{array}{l}\text { Number of } \\
\text { Items }\end{array}$ \\
Cronbach's Alpha & Items 1 & \\
\hline 0.810 & 0.811 & 2 \\
\hline
\end{tabular}

Panel B: The changes in Cronbach's alpha when items from the experience construct are deleted

\begin{tabular}{llllll}
\hline & $\begin{array}{l}\text { Scale Mean if Item } \\
\text { Deleted }\end{array}$ & $\begin{array}{l}\text { Scale Variance if Item } \\
\text { Deleted }\end{array}$ & $\begin{array}{l}\text { Corrected Item } \\
\text {-Total } \\
\text { Correlation }\end{array}$ & $\begin{array}{l}\text { Squared } \\
\text { Multiple } \\
\text { Correlation }\end{array}$ & $\begin{array}{l}\text { Cronbach's } \\
\text { Alpha if Item } \\
\text { Deleted }\end{array}$ \\
\hline Question 1 & 4.30 & 0.312 & 0.682 & 0.466 & 0.426 \\
Question 2 & 4.34 & 0.275 & 0.682 & 0.466 & 0.515 \\
\hline
\end{tabular}

Panel A of Table 5 reports that the Cronbach's alpha coefficient for the experience construct is 0.81 which is an acceptable value and is internally reliable. Panel B of Table 5 shows that both questions for the experience variable have high reliability measures with Cronbach's alpha and with deletion of every question individually the coefficient does not exceed 0.81 , which means that all elements of the experience variable are internally consistent and valid to measure the construct.

Table 6.

Panel A: Cronbach's alpha for the routine construct

\begin{tabular}{lll}
\hline & Cronbach's & \\
& $\begin{array}{l}\text { Alpha Based on } \\
\text { Standardized } \\
\text { Items }\end{array}$ & $\begin{array}{l}\text { Number of } \\
\text { Items }\end{array}$ \\
\hline 0.697 & 0.700 & 3 \\
\hline
\end{tabular}

Panel B: The changes in Cronbach's alpha when items from the routine construct are deleted

\begin{tabular}{llllll}
\hline & $\begin{array}{l}\text { Scale Mean if Item } \\
\text { Deleted }\end{array}$ & $\begin{array}{l}\text { Scale Variance if Item } \\
\text { Deleted }\end{array}$ & $\begin{array}{l}\text { Corrected Item } \\
\text {-Total } \\
\text { Correlation }\end{array}$ & $\begin{array}{l}\text { Squared } \\
\text { Multiple } \\
\text { Correlation }\end{array}$ & $\begin{array}{l}\text { Cronbach's } \\
\text { Alpha if Item } \\
\text { Deleted }\end{array}$ \\
\hline Question 1 & 6.23 & 3.757 & 0.531 & 0.327 & 0.582 \\
Question 2 & 6.17 & 3.977 & 0.426 & 0.187 & 0.716 \\
Question 3 & 6.39 & 3.665 & 0.590 & 0.367 & 0.509 \\
\hline
\end{tabular}

Panel A of Table 6 reports that the Cronbach's alpha coefficient for the routine construct is 0.697 which is an acceptable value and is internally reliable. Panel B of Table 6 shows that all research questions for the routine variable have high reliability measures with Cronbach's alpha and with deletion of every question individually the coefficient does not exceed 0.697, except for the second question relating to the recruitment process. When this question is deleted the coefficient increases to 0.716 , this increase is significant and as a result this question must be deleted. However, the other elements of the routine variable are internally consistent and valid to measure the construct. 
Table 7 .

Panel A: Cronbach's alpha for the skills construct

\begin{tabular}{lll}
\hline & $\begin{array}{l}\text { Cronbach's } \\
\text { Alpha Based on } \\
\text { Standardized }\end{array}$ & $\begin{array}{l}\text { Number of } \\
\text { Items } \\
\text { Items }\end{array}$ \\
\hline 0.734 & 0.761 & 3 \\
\hline
\end{tabular}

Panel B: The changes in Cronbach's alpha when items from the skills construct are deleted

\begin{tabular}{llllll}
\hline & $\begin{array}{l}\text { Scale Mean if Item } \\
\text { Deleted }\end{array}$ & $\begin{array}{l}\text { Scale Variance if Item } \\
\text { Deleted }\end{array}$ & $\begin{array}{l}\text { Corrected Item } \\
\text {-Total } \\
\text { Correlation }\end{array}$ & $\begin{array}{l}\text { Squared } \\
\text { Multiple } \\
\text { Correlation }\end{array}$ & $\begin{array}{l}\text { Cronbach's } \\
\text { Alpha if Item } \\
\text { Deleted }\end{array}$ \\
\hline Question 1 & 7.79 & 1.829 & 0.655 & 0.484 & 0.536 \\
Question 2 & 7.76 & 2.245 & 0.588 & 0.428 & 0.647 \\
Question 3 & 8.18 & 1.579 & 0.498 & 0.255 & 0.777 \\
\hline
\end{tabular}

Panel A of Table 7 reports that the Cronbach's alpha coefficient for the skills construct is 0.734 which is an acceptable value and is internally reliable. Panel B of Table 7 shows that all research questions for the skills variable have high reliability measures with Cronbach's alpha and with deletion of every question individually the coefficient does not exceed 0.734, except for the third question relating to if the managers delegate to subordinates. When this question is deleted the coefficient increases to 0.777 but this increase is insignificant and will be neglected. However, the other elements of the skills variable are internally consistent and valid to measure the construct.

Table 8 .

Panel A: Cronbach's alpha for the knowledge construct

\begin{tabular}{lll}
\hline & $\begin{array}{l}\text { Cronbach's } \\
\text { Alpha Based on } \\
\text { Standardized } \\
\text { Items }\end{array}$ & $\begin{array}{l}\text { Number of } \\
\text { Items }\end{array}$ \\
\hline 0.627 & 0.626 & 3 \\
\hline
\end{tabular}

Panel B: The changes in Cronbach's alpha when items from the knowledge construct are deleted

\begin{tabular}{llllll}
\hline & $\begin{array}{l}\text { Scale Mean if Item } \\
\text { Deleted }\end{array}$ & $\begin{array}{l}\text { Scale Variance if Item } \\
\text { Deleted }\end{array}$ & $\begin{array}{l}\text { Corrected Item } \\
\text {-Total } \\
\text { Correlation }\end{array}$ & $\begin{array}{l}\text { Squared } \\
\text { Multiple } \\
\text { Correlation }\end{array}$ & $\begin{array}{l}\text { Cronbach's } \\
\text { Alpha if Item } \\
\text { Deleted }\end{array}$ \\
\hline Question 1 & 8.85 & 0.631 & 0.492 & 0.254 & 0.443 \\
Question 2 & 8.78 & 0.729 & 0.460 & 0.230 & 0.496 \\
Question 3 & 8.75 & 0.792 & 0.362 & 0.132 & 0.626 \\
\hline
\end{tabular}

Panel A of Table 8 reports that the Cronbach's alpha coefficient for the knowledge construct is 0.627 which is an acceptable value and is internally reliable. Panel B of Table 8 shows that all research questions for the knowledge variable have high reliability measures with Cronbach's alpha and with deletion of every question individually the coefficient does not exceed 0.627 , which means that all elements of the knowledge variable are internally consistent and valid to measure the construct. 
Table 9. Pearson correlations between the dynamic capabilities

\begin{tabular}{lllllll}
\hline & Rank & Knowledge & Skills & Routine & Experience & Technology \\
\hline Rank & 1.000 & & & & & \\
Knowledge & 0.009 & 1.000 & & & & \\
Skills & 0.001 & 0.028 & 1.000 & & & \\
Routine & 0.800 & 0.030 & -0.051 & 1.000 & & \\
Experience & 0.018 & 0.048 & 0.191 & -0.051 & 1.000 & \\
Technology & 0.915 & 0.086 & -0.089 & 0.767 & 0.040 & 1.000 \\
\hline
\end{tabular}

Table 9 reports correlations between the dynamic capabilities. The results show that none of the correlations is high enough to cause estimation problems. In unreported results, the authors ran Chi-square tests and the results indicated that four of the six dynamic capabilities (experience, skills, firm characteristics and knowledge) have a role in building a competitive advantage. That is to say, hypotheses $1,3,4$ and 5 are supported by the results.

\section{Discussion and Conclusion}

The results support hypothesis 1 which states that "There is a significant relationship between the "experience" dynamic capability and the competitive advantage sustainability in Egyptian pharmaceutical firms.' The results indicate that experience helps managers in analyzing market data and helps them in predicting and dealing with the future market changes. The results reject hypothesis 2 which states that 'There is a significant relationship between the "routine" dynamic capability and the competitive advantage sustainability in Egyptian pharmaceutical firms.' The results show that applying quality procedures in standard operating procedures and conducting regular employee and customer surveys will provide the companies with competitive advantage sustainability. However, there was no statistical internal consistency for whether applying rigid hiring procedures leads to competitive advantage sustainability.

The results support hypothesis 3 which states that "There is a significant relationship between the "skills" dynamic capability and the competitive advantage sustainability in Egyptian pharmaceutical firms.' The results indicate that applying a rigid training plan, continuous employee training and managers delegating to their subordinates all lead to competitive advantage sustainability. The results support hypothesis 4 which states that 'There is a significant relationship between the "firm characteristics" dynamic capability and the competitive advantage sustainability in Egyptian pharmaceutical firms.' The results indicate that firm characteristics such as company size, number of employees, order of entry into the market and the company's products portfolio all lead to competitive advantage sustainability.

The results support hypothesis 5 which states that "There is a significant relationship between the "knowledge" dynamic capability and the competitive advantage sustainability in Egyptian pharmaceutical firms.' The results indicate that continuous collection of new information, better decision making due to gathering information from internal and external sources and applying horizontal knowledge management all lead to competitive advantage sustainability. The results reject hypothesis 6 which states that "There is a significant relationship between the "technology" dynamic capability and the competitive advantage sustainability in Egyptian pharmaceutical firms.' The importance of the technology dynamic capability is more apparent in the ranked companies which operate in the Egyptian pharmaceutical market. This is contrary to the results for the non-ranked companies which do not have viable $R \& D$ strategies due to the financial burden that accompanies $R \& D$ spending. The non-ranked companies do not consider technology as an important dynamic capability to build a sustainable competitive advantage. However, the ranked companies do consider that technology leads to competitive advantage sustainability.

\subsection{Limitations}

Designing the questionnaire and formulating the questions to target the required field was challenging, given that the topic is dynamic and the business scene in Egypt has witnessed drastic changes due to the continuous political upheaval that the country has been experiencing since January 2011. Another limitation of the study was the translation of the questionnaires from Arabic to English then back to Arabic (Elsaid and Elsaid, 2012). The authors tried to overcome this limitation by using the Werner and Campbell (1970), decentring method. A limitation with the 
methodology used in the study is that using judgmental sampling could potentially cause a selection bias (Heckman, 1979). The bias in the sample arises because there is no randomization when obtaining the sample. This bias might lead to a reduction in the generalizability of the results of the study.

\subsection{Implications}

This study helps to shed some light on the pharmaceutical sector in Egypt. There is very little previous research regarding models, trends or answers to questions on the pharmaceutical market traits in Egypt. In addition there is little information available regarding Egyptian pharmaceutical company performance, capabilities and internal analysis. The study should also assist pharmaceutical companies in Egypt in directing their investments properly and in determining the weaknesses in their dynamic capabilities that need to be addressed and strengthened. To the best of our knowledge, there is no previous research that examines the importance of dynamic capabilities and their constructs on competitive advantage sustainability in the Egyptian pharmaceutical sector.

\section{References}

Aime, F., Johnson, S., Ridge, J., \& Hill, A. (2010). The routine may be stable but the advantage is not: competitive implications of key employee mobility. Strategic Management Journal, 31, 75-87. https://doi.org/10.1002/smj.809

Ambrosini, V., Bowman, C., \& and Collier, N. (2009). Dynamic capabilities: an exploration of how firms renew their resource base. British Journal of Management, 20, 9-24. https://doi.org/10.1111/j.1467-8551.2008.00610.x

Andrews, K. (1971). The concept of corporate strategy. Homewood, IL: Dow Jones-Irwin.

Argote, L. (1999). Organizational learning: creating, retaining, and transferring knowledge. Boston, MA: Kluwer Academic Publishers.

Audea, T., Stephen, T., \& John, C. (2005). HRM professionals and their perceptions of HRM and firm performance in the Philippines. The International Journal of Human Resource Management, 16, 532-552. https://doi.org/10.1080/09585190500051589

Azarian, M., Yunus, Y., \& Dahlan, A. (2013). Effectiveness of knowledge management in achieving success in Malaysian government agencies. Journal of Information Management and Business Review, 5, 324-330. Available: https://ifrnd.org/journal/index.php/imbr/article/view/1058/1058 (April 10, 2017)

Barney, J. (1991). Firm resources and sustainable competitive advantage. Journal of Management, 17, 99-120. https://doi.org/10.1177/014920639101700108

Bharadwaj, S., Varadarajan, P., \& Fahy, J. (1993). Sustainable competitive advantage in service industries: a conceptual model and research propositions. Journal of Marketing, 57, 83-99. https://doi.org/10.2307/1252221

Bowman, C., \& Ambrosini, V. (2003). How the resource-based and dynamic capability views of the firm inform corporate-level strategy. British Journal of Management, 14, 289-303. https://doi.org/10.1111/j.1467-8551.2003.00380.x

Brislin, R. (1976). Comparative research methodology: cross-cultural studies. International Journal of Psychology, 11, 215-229. https://doi.org/10.1080/00207597608247359

Browning, V., Edgar, F., Gray, B., \& Garrett, T. (2009). Realizing competitive advantage through HRM in New Zealand service industries. The Service Industries Journal, 29, 741-760. https://doi.org/10.1080/02642060902749237

Chen, M. (1996). Competitor analysis and inter-firm rivalry: toward a theoretical integration. Academy of Management Review, 21, 100-134. https://doi.org/10.5465/AMR.1996.9602161567

Davenport, S., Campbell-Hunt, C., \& Solomon, J. (2003). The dynamics of technology strategy: an exploratory study. $R \& D$ Management, 33, 481-499. https://doi.org/10.1111/1467-9310.00312

Eisenhardt, K., \& Martin, J. (2000). Dynamic capabilities: what are they? Strategic Management Journal, 21, 1105-1121. https://doi.org/10.1002/1097-0266(200010/11)21:10/11<1105::AID-SMJ133>3.0.CO;2-E

Elsaid, A., \& Elsaid, E. (2012). Sex stereotyping managerial positions: a cross-cultural comparison between Egypt and the U.S.A. Gender in Management: An International Journal, 27, 81-99. https://doi.org/10.1108/17542411211214149

Field, A. (2005). Discovering statistics using SPSS. London, UK: Sage. 
Foster, R. (1986). Innovation: the attacker's advantage. New York, NY: Summit Books. https://doi.org/10.1007/978-3-322-83742-4

Frery, F. (2006). The fundamental dimensions of strategy. MIT Sloan Management Review, 48, 71-75.

George, D., \& Mallery, P. (2003). SPSS for Windows step by step: A simple guide and reference. Boston, MA: Allyn $\&$ Bacon.

Greenberg, B., Goldstucker, J., \& Bellenger, D. (1977). What techniques are used by marketing researchers in business. Journal of Marketing, 41, 62-68. https://doi.org/10.2307/1250635

Hair, J., Black, W., Babin, B., \& Anderson, R. (2010). Multivariate data analysis. Upper Saddle River, NJ: Pearson Education.

Hansen, M. (1999). The search-transfer problem: the role of weak ties in sharing knowledge across organization subunits. Administrative Science Quarterly, 44, 82-111. https://doi.org/10.2307/2667032

Heckman, J. (1979). Sample selection bias as a specification error. Econometrica, 47, 153-161. https://doi.org/10.2307/1912352

Higginbottom, G. (2004). Sampling issues in qualitative research. Nurse Researcher, 12, 7-19. https://doi.org/10.7748/nr2004.07.12.1.7.c5927

King, A., \& Tucci, C. (2002). Incumbent entry into new markets niches: the role of experience and managerial choice in the creation of dynamic capabilities. Management Science, 48, 171-186. https://doi.org/10.1287/mnsc.48.2.171.253

Kogut, B., \& Zander, U. (1992). Knowledge of the firm, combinative capabilities, and the replication of technology. Organization Science, 3, 383-397. https://doi.org/10.1287/orsc.3.3.383

Liqin, R., Guangya, X., \& Koos, K. (2010). Sustainable competitive advantage and marketing innovation within firms: a pragmatic approach for Chinese firms. Management Research Review, 33, 79-89. https://doi.org/10.1108/01409171011011580

Littler, J. (2005). Beyond the boycott: anti-consumerism, cultural change and limits of reflexivity. Cultural Studies, 19, 227-252. https://doi.org/10.1080/09502380500077771

Mahoney, J., \& Pandian, J. (1992). The resource-based view within the conversation of strategic management. Strategic Management Journal, 13, 363-380. https://doi.org/10.1002/smj.4250130505

Makadok, R. (2001). Toward a synthesis of the resource-based and dynamic-capability views of rent creation. Strategic Management Journal, 22, 387-401. https://doi.org/10.1002/smj.158

Penrose, T. (1959). The theory of the growth of the firm. New York, NY: John Wiley.

Porter, M. (1985). The competitive advantage: creating and sustaining superior performance. New York, NY: Free Press.

Porter, M. (1987). From competitive advantage to corporate strategy. Harvard Business Review, 65, 43-59.

Porter, M. (1991). Towards a dynamic theory of strategy. Strategic Management Journal, 12, 95-117. http://dx.doi.org/10.2307/2486436

Prahalad, C., \& Hamel, G. (1990). The core competence of the corporation. Harvard Business Review, 68, 79-91.

Ray, G., Barney, J., \& Muhanna, A. (2004). Capabilities, business processes, and competitive advantage: choosing the dependent variable in empirical tests of the resource-based view. Strategic Management Journal, 25, 23-37. https://doi.org/10.1002/smj.366

Robles, M. (2012). Executive perceptions of the top 10 soft skills needed in today's workplace. Business Communication Quarterly, 75, 453-465. https://doi.org/10.1177/1080569912460400

Rouse, J., \& Daellenbach, U. (1999). Rethinking research methods for the resource-based perspective: isolating sources of sustainable competitive advantage. Strategic Management Journal, 20, 487-494. http://dx.doi.org/10.2307/3094166

Shrader, C., Blackburn, V., \& Iles, P. (1997). Women in management and firm financial performance: anexploratory study. Journal of Managerial Issues, 9, 355-372.

Sitkin, S. (1992). Learning through failure: the strategy of small losses. In Research in Organizational Behavior. Eds. 
L. Cummings and B. Staw. Greenwich, CT: JAI press.

Teece, J. (1998). Research directions for knowledge management. California Management Review, 40, $289-292$.

Utterback, J., \& Abernathy, W. (1975). A dynamic model of process and product innovation. Omega, 3, $639-656$. https://doi.org/10.1016/0305-0483(75)90068-7

Werner, O., \& Campbell, D. 1970. Translating, working through interpreters, and the problem of decentering. In $A$ handbook of method in cultural anthropology. Eds. R. Naroll and R. Cohen, R. New York, NY: American Museum of Natural History.

Williams, D., \& Leask, J. (2011). People, process, technology strategy for enterprise 2.0. Available: https://www.boozallen.com/content/dam/boozallen/media/file/People-Process-Technology-Enterprise2.pdf (July 6, 2016).

Winter, S. (2000). The satisficing principle in capability learning. Strategic Management Journal, 21, 981-996. https://doi.org/10.1002/1097-0266(200010/11)21:10/11<981::AID-SMJ125>3.0.CO;2-4

Winter, S. (2003). Understanding dynamic capabilities. Strategic Management Journal, 24, 991-995. https://doi.org/10.1002/smj.318

Zollo, M., \& Winter, S. (2002). Deliberate learning and the evolution of dynamic capabilities. Organization Science, 13, 339-351. https://doi.org/10.1287/orsc.13.3.339.2780

\section{Appendix}

\section{Experience}

Question 1:

Managers have the capability to predict future market changes.

$\begin{array}{llll}\text { S.D } & \text { D } & \text { N }\end{array}$

S.A

Question 2:

Dealing with market changes is somewhat easy for our company's managers.

S.D

D

$\mathrm{N}$

A

S.A

\section{Routine}

Question 1:

Applying quality procedures takes a big part of the company's workforce.

S.D

D

$\mathrm{N}$

A

S.A

Question 2:

Human Resources department is applying exhaustive procedures in recruiting employees.

Questions 3:

The company conducts regular employee and customer satisfaction surveys.

$\begin{array}{lllll}\text { S.D } & \mathrm{D} & \mathrm{N} & \mathrm{A} & \text { S.A }\end{array}$

\begin{tabular}{lllll} 
S.D & $\mathrm{D}$ & $\mathrm{N}$ & $\mathrm{A}$ & S.A \\
\hline
\end{tabular}




\section{$\underline{\text { Skills }}$}

Question 1:

The company applies a rigid training plan that helps it achieve its targets.

$\begin{array}{llll}\text { S.D } & \text { D } & \mathrm{N} & \text { A }\end{array}$

S.A

Question 2:

Continuous training allows employees to gain more information about their work and the market.

S.D

$\mathrm{D}$

$\mathrm{N}$

A

S.A

Questions 3:

Managers delegate some of their authority to their subordinates.

S.D

D

$\mathrm{N}$

A

S.A

\section{Firm Characteristics}

Question 1:

The company's size, order of entry into the market and the product portfolio (e.g., type of product market and number of the products) have a great impact on its performance in the market.

S.D

D

$\mathrm{N}$

A

S.A

\section{Knowledge}

Question 1:

New information is continuously gathered by employees.

S.D

$\mathrm{D}$

$\mathrm{N}$

A

S.A

Question 2:

Gathering enough information from several different sources internally and externally leads to more accurate decision making.

Questions 3:

Applying horizontal knowledge management improves the decision making process.
S.D

D

$\mathrm{N}$

A

S.A
S.D
D
A 


\section{Technology}

Question 1:

The company is using the most up-to-date technology in the market.

S.D

D

$\mathrm{N}$

A

S.A

Question 2:

The updated technology helps the company develop its market position.

S.D

D

$\mathrm{N}$

A

S.A

Questions 3:

$R \& D$ is the backbone of the company.

$\begin{array}{lllll}\text { S.D } & \text { D } & \text { N } & \text { A } & \text { S.A }\end{array}$

Questions 4:

The company is a technology seeker.

$\begin{array}{lllll}\text { S.D } & \text { D } & \text { N } & \text { A } & \text { S.A }\end{array}$

Questions 5:

The company has a software based knowledge management system.

$\begin{array}{lllll}\text { S.D } & \mathrm{D} & \mathrm{N} & \mathrm{A} & \text { S.A }\end{array}$

S.D: Strongly Disagree

D: Disagree

N: Neutral

A: Agree

S.A: Strongly Agree 